\title{
Islands of memory, islands of trauma: The case of Dongzhou, Hengyang, China
}

\author{
Gang Hong \\ Guangdong Polytechnic of Science and Technology, China \\ Sun Yat-sen University, China \\ hongg3@mail.sysu.edu.cn
}

\begin{abstract}
This paper examines the complex interaction between island histories and island geographies by presenting a case study of Dongzhou Island, Hengyang, China, contextualized through several critical island events. Employing a wide range of methods including archival research, textual and media analysis, field and map observations, semi-structured interviews, and informal interaction, the research is broadly framed in the problematic of geographical memory consisting of hard island memory, soft island memory, and lived island memory. Particular attention is paid to the construction of Dongzhou Island's cultural trauma based on three difficult island histories: mass killing, radical planning, and uneven development. Findings indicate that these memories coexist on or about the island, in virtual isolation from each other. It is argued that while hard memory constructs the island as a petrified landmark, soft memories murmur about the forgotten or obscured pains of a small island that bears witness to the violence of war and progress. The theoretical and practical implications regarding the role of place memory in rejuvenating local cultures are also proposed.
\end{abstract}

Keywords: China, Dongzhou Island, geographical memory, heritage, river islands, trauma

https://doi.org/10.24043/isj.131 • Received April 2020, accepted August 2020

C 2020 - Institute of Island Studies, University of Prince Edward Island, Canada.

\section{Introduction}

Dongzhou is a small island situated in the Xiangjiang River, a major waterway that threads through the entire territory of Hengyang municipality, China. The island, oblong in shape, is approximately 2000 meters long and 200 meters wide, with beach area totalling approximately $1.67 \mathrm{~km}^{2}$. The area of water to the east of the island is about 300 meters wide, while that to the west is around 500 meters wide (Hao et al., 2012). Despite recent radical development of the island, there have been no land reclamation efforts, with the exception of bank reinforcement and beautification.

Surrounding Dongzhou is the mainland city of Hengyang, situated in the central part of Hunan province, a region that is relatively underdeveloped economically, but rich in historical resources (Hengyang Municipal Chronicle Office, 2014). Before the construction of a bridge in 2018, there had been no fixed link between the island and the city, and transport had been by ferry (and, for some islanders, swimming in summer). Like many cities in Hunan 
Province (e.g., Changsha; Zhuzhou), the river divides the city into two parts. The west bank has typically been the political, commercial, and cultural center, and the east bank a quasirural fringe area mixing agricultural communities, old state-owned industry clusters, and military bases, although, with the recent construction of a bridge on the east side, the tide may turn. Some promising signs of an emerging service economy and related property boom can already be glimpsed, though there is still much that cannot be foreseen. While the future of life on the riverbanks in terms of urbanization is uncertain, the fate of the island itself is sealed; its inhabited, rural past is gone and now it exists as an uninhabited tourist park on the fringe of Hengyang, serving as a petrified landmark symbolizing the city's dream future of ecology, culture, and leisure.

There is usually a rupture between island experience and island representation. The status of being an island is not necessarily foregrounded in the experience of the island. Insofar as mainstream history of the city of Hengyang goes, Dongzhou's islandness has been conspicuously exploited or/and recognized in three major events. Indeed, it could be argued that there have been three islanding moments: firstly, the sanctification of the island into a sacred academy during the late- $19^{\text {th }}$ Century in memory of Wang Fuzhi, a locally born radical intellectual recluse; secondly, the conversion of the island into a slaughterhouse as Chinese prisoners of war were tortured and executed by the Japanese army after a 47-day siege in the autumn of 1944; and, thirdly, the wholesale transformation of the island into a tourist enclave at the expense of a total relocation of its former inhabitants and a radical urban renewal of not just the islandscape but also the quasi-rural village on the riverbanks. One way or another, these moments in the island's history have inescapably had recourse to four assumed aspects of islandness: boundedness, smallness, isolation, and littorality (Kelman, 2020). All three moments are closely associated with the issue of geographical memory, while the latter two also pertain to potentially traumatic memories.

This paper endeavors to examine the complex interaction between island histories and island geographies through the theoretical lenses of geographical memory and cultural trauma. It will start with a relevant description of the island and its environs. The description will be followed by a development of the theoretical framework integrating discussions of geographical memory, cultural trauma, and island spatiality. In the analytical parts, Dongzhou Island's geographical memories and the processes of cultural trauma that took place on and around it will be examined. A conclusion will be drawn consisting of a summary of major findings, a plea for rethinking what constitutes island heritage and how alternative representations are possible. The theoretical and practical implications of studying island memories are also proposed.

\section{The river, the island, and the city}

There are two broad ways to conceptualize the tension between space and place. I would like to call one the liberalizing tradition and the other the essentializing tradition. The former is represented by Massey $(2005$, p. 5), who interprets space as a process of open possibilities and place as the "locus of denial." By contrast, Tuan (1977, p. 6) holds that space alone is impersonal and devoid of meaning and purpose; to make it human, you have to frame it into a place against familiar surroundings. In this section, I will stick to Tuan's take on tension, framing the city of Hengyang against its most important reference: water. 
To some extent, all regions in China are defined by the element of water, but some more so than others (Ball, 2017). The Xiangjiang River, with its numerous tributaries, is the most important geographical reference point in Hunan Province. The river has such a central place in the region's geographical, social, and cultural identity that the abbreviated alias of the province, Xiang, is derived from the name of the river. The Xiangjiang River is about 856 $\mathrm{km}$ in length and its basin within the province is estimated to cover about $94,660 \mathrm{~km}^{2}$. The section of the river in the jurisdiction of Hengyang is about $266 \mathrm{~km}$ long, which amounts to more than one-fourth of its overall length. The river-particularly its periodic threat of flooding - is imprinted in the memories of its residents (Water Resources Chronicle Office of Hengyang Municipal Water Resources Bureau, 2014, p. 469, pp. 7-70).

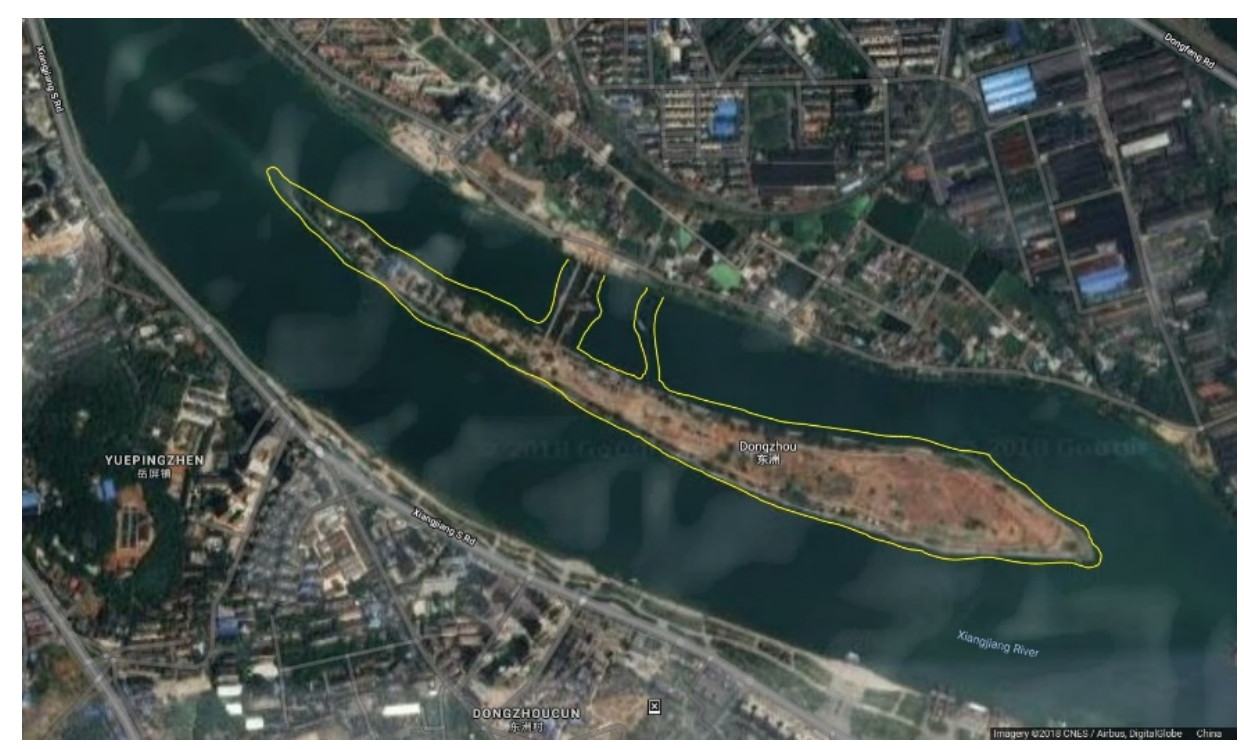

Figure 1: Dongzhou Island, under redevelopment. Source: Modified from Imagery (C) 2018 TerraMetrics, DigitalGlobe, CNES/Airbus, Digital Globe, Map data C 2018 Google.

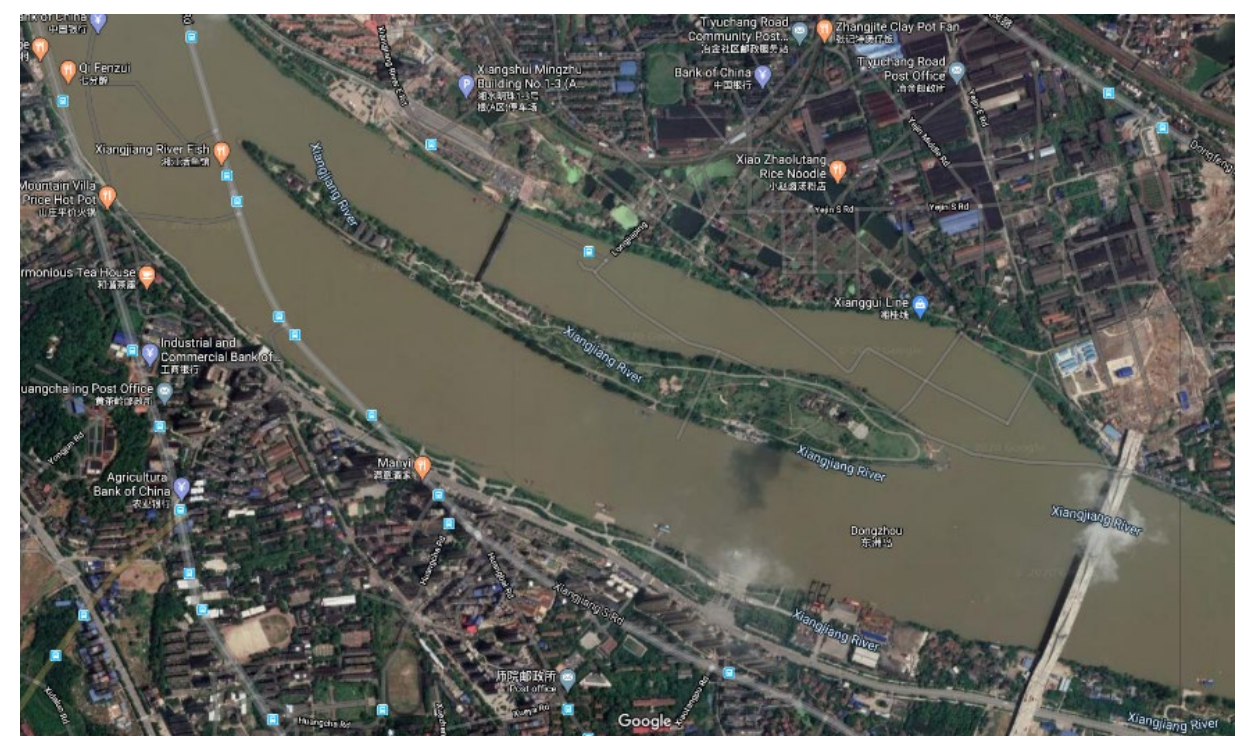

Figure 2: Dongzhou Island after redevelopment. Source: Imagery (C) 2020 TerraMetrics, DigitalGlobe, CNES/Airbus, Digital Globe, Map data C 2020 Google. 
There are two words in Chinese that can refer to islands: dao (岛) and zhou (洲). The former signifies, ideographically, a mountain with a bird on top of it without any indication of water, and is currently the most commonly used word for islands. The latter derives from a more ancient usage that signifies a piece of land in the water, and has been used to refer to both maritime and river islands. In view of place names in today's China, the narrow sense of the word is more often associated with smaller islands in rivers and lakes, though the semantic distinction is not strictly enforced. Islands form a major part of the Xiangjiang riverscape. There are estimated to be over 1000 islands in the mainstream and its various tributaries, most of which are scattered in the middle and lower section of the river. Most of these islands formed through sedimentation from the upper stretch of the river. Though they differ in size, the majority of them are small (less than $1 \mathrm{~km}^{2}$ ), surrounded by water, and uninhabited. There are bigger inhabited islands that hold villages, but island populations in general have been shrinking due to tourism, seasonal floods, and transportation challenges.

Around 200 islands in the Xiangjiang River are believed to have potential for tourism development. However, a combination of factors, such as distance from the urban area and relatively small size, prevents most islands situated in remote rural areas from being subjected to human engineering, thus leaving the real development potential to those islands situated in urban and suburban areas. Local researchers list 15 islands in the Xiangjiang River that have been assessed to be of tourism value, four of which are within the territory of Hengyang (Huang \& Peng, 2012). These 15 islands are classified into three regional groups by local researchers: four in the upper section of the river, four in the middle section, and seven in the lower section: Dongzhou is in the 'middle section' group and, while it shares some common ecological resources with kindred islands in the group, it is mainly characterized by its historical heritage rather than ecological features (Huang \& Peng, 2012).

As is evident in official and satellite maps, Dongzhou Island is situated near the heart of the city of Hengyang (see Figures 1 \& 2; Kuang \& Rao, 2008). However, experientially, its position as an urban fixture is dubious. Despite its relative proximity to the urban center, Dongzhou Island was long considered a backwater on the rural-urban fringe of the city that relied on governmental subsidies, fishing, small-scale agriculture, and recreational service. Before 2001, the island and its village had been administered by the Suburban People's Government. With the subsequent wave of urban expansion and tourism development, the island was incorporated into Yanfeng District, the old urban heart of Hengyang (Hengyang Municipal Chronicle Office, 2014, p. 73).

Before mass tourism, Dongzhou's social life was characterized by its poor but relatively self-sufficient local economy, its narrow but also more ecological living space (compared with the mainland city), and a relatively insulated community with its own village committee, primary school, and social networks. Unlike islands in more culturally diverse environments, ethnicity is not a variable here since all former islanders are descendants of Han immigrants. The combination of mass tourism and generational change has also arguably mitigated the formation of a separate island identity. While there was no doubt a unique island life before mass tourism, the question of a completely separate island identity is debatable. 


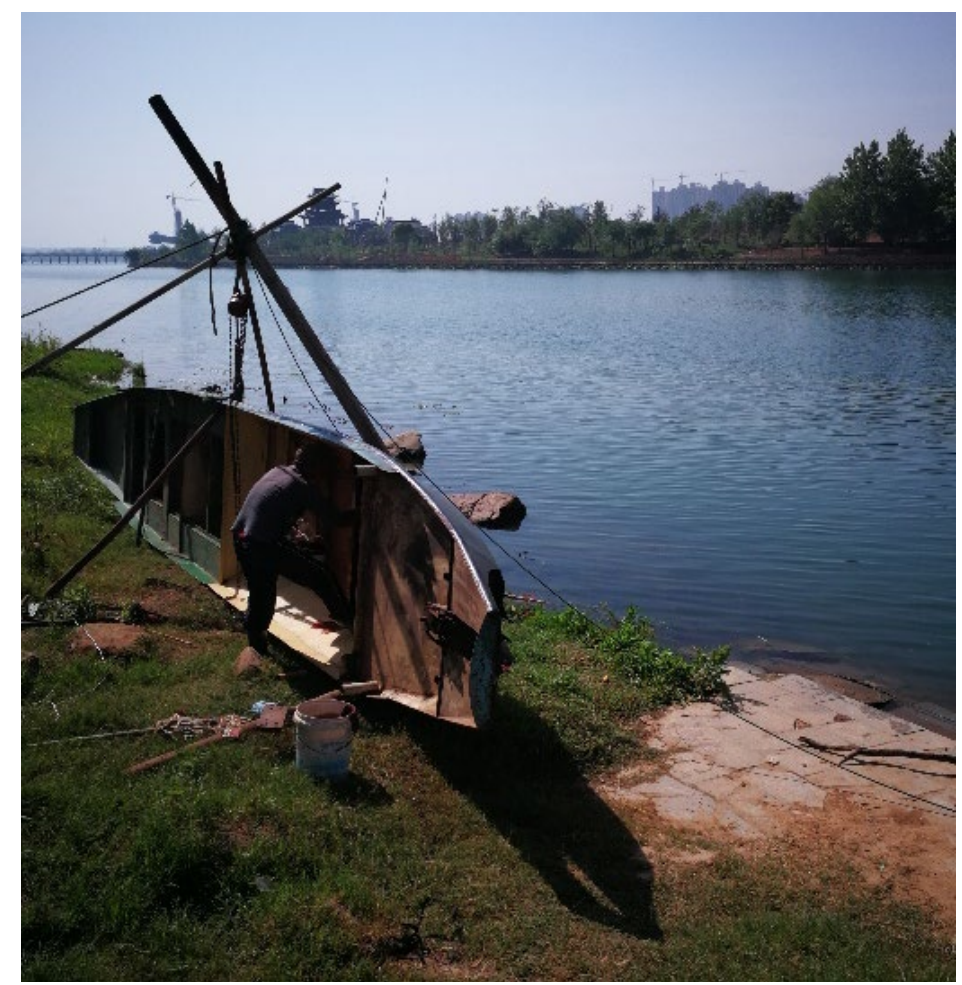

Figure 3: A villager repairing his boat on the east riverbank facing Dongzhou Island. Source: (C) Hong Gang, 2018.

\section{Geographical memory, cultural trauma, and island spatiality}

The present paper is broadly designed within the frame of geographical memory in order to examine the tension between island histories and island geographies. In the context of Dongzhou, an important sub-issue of geographical memory is trauma-of which amnesia often plays a part. When examining the relationship between trauma and place, a dynamic cultural constructivist approach will be adopted in order to shed light on the complex interaction between place making and cultural processes.

Human geography sees memories as an "inherently geographical activity" in the sense that places "store and evoke personal and collective memories" (Gregory et al., 2009, p. 453). Far from being an inert container of mental processes, geographical memory is an active agent in the shaping of both imaginative and material geographies. Aspects of the built landscape, such as museums, monuments, and memorials, play a key role in the cultivation of collective consciousness and, by extension, geographical memory. In this regard, Halbwachs (1992) was a pioneer, emphasizing the importance of anchoring memories to physical objects in inducing a sense of togetherness. Influenced by this early tradition founded on a physical/symbolic dichotomy, Nora (1997, pp. 22-43) shifted his attention towards a distinction between spontaneous, authentic memories and self-consciously created ones embedded in what he called "lieux de mémoire".

Though the 'powerful' and 'elites' are usually the dominant groups in shaping collective memories in their hard form, the production and consumption of these memory projects is by no means a one-way street. On the contrary, the cultural meaning of these crafted memories is often wrought with conflicts, as can be seen in the examples of Germany and America (Foote, 2003; Till, 2005). 
In view of the aforementioned conflicts, it is necessary to examine the tension between different sources of memory associated with places. Among them, popular memory is an important alternative vehicle through which monolithic renditions of place memories could be complemented and even contested (Gregory et al., 2009). A rich body of work has developed championing the memory projects of marginalized, subaltern, and grassroot populations, whose place memories are interpreted as bearing traces of trauma, that is, a counter force to the established narration memory. However, intellectual approaches to trauma vary from context to context (see Alexander, 2012; Atkinson \& Richardson, 2013; Caruth, 1995; Caruth, 1996; Felman, 2002; Herman, 1992; Laud \& Auerhahn, 1993; van der Kolk, 2014 for key applications of trauma studies in both psychoanalytical/cultural, collective/individual, and social/affective contexts). Generally speaking, whereas the naturalistic approach views traumas largely as originating from the outer world, the cultural approach, without necessarily denying the physiological origin, focuses on the social memorization, representation, and imagination of a radical event. As key theorist J.C. Alexander (2012, p. 6) puts it, cultural trauma occurs "when members of a collectivity feel they have been subjected to a horrendous event that leaves indelible marks on their group consciousness, marking their memories forever and changing their future identity in fundamental and irrevocable ways."

In the section analyzing the processes of cultural trauma on Dongzhou Island, I acknowledge the naturalistic foundation of radical events that can potentially alter island identity, identifying traumatic island histories in line with the broad definition of trauma as an "agent," "force," or "mechanism" that causes an "emotional upset" (Trauma, n.d.). In the case of Dongzhou, the semantic stress falls on 'emotional upset', emphasizing the subjective, experiential nature of trauma. Accordingly, violent, radical, and insidious versions of traumatic events are all considered; however, the dominant approach will be a cultural constructivist one that seeks to understand how different groups appropriate or do not appropriate significant island events and experiences as traumas.

Geographical memory and cultural trauma can be useful methodologies in many contexts, and their application to an island case is perfectly justified. Human landscapes throughout the globe have undergone radical changes in the epoch of the Anthropocene, but islands have been more susceptible and sensitive to these changes due to their perceived idiosyncrasies (Pugh, 2018). The island is considered to be one of the four natural environments that figure prominently in both western and non-western cultures, and islands' central place as mythical geographies is all the more so in western cultures (Gillis, 2007; Tuan, 1990 , p. 247). However, islands have often served as 'props' for mythologized geographies, outposts of aberrant exoticism, Robinsonade colonialism, ideal destinations for vacation, and even island communities' spontaneous maneuvering of the image imposed on them externally (Baldacchino, 2008). One recent debate revolves around the dualistic trope of vulnerability/resilience in a development context, wherein the four aspects of islandness are assumed to have induced island vulnerability as is examined in various fields, ranging from social science and natural science to sustainability policy and literature (Kelman, 2020). Opinions are diverse; some stress the limits of emphasizing the inherent vulnerabilities of small island states and territories and the imperative to move beyond vulnerability and see them as "doggedly perseverant and cleverly opportunistic" (Baldacchino, 2015, p. 1). Others question the ethical validity of the resilience trope and the over-romanticized condition of 'Indigenous' 
knowledge (Pugh, 2018). There are still others that take a more nuanced position regarding the resilience trope as manufactured stereotypes that can be "truth for some islands" and have "limited scope for others" (Kelman, 2020, p. 4). With this in mind, an investigation of the interrelation between islands, geographical memory, and cultural trauma makes both ethical and epistemological sense.

In light of the aforementioned review, the paper's main research questions can be summarized as follows:

- What different sources and forms of geographical memory are there in this case and how are they related to each other?

- How are traumatic island histories remembered or forgotten in this case?

- What are the theoretical and practical implications of studying island memories?

To answer these questions, different sources of data will be used holistically and critically in order to go beyond the constraints posed by particular discourses and bring into relief the dynamic interaction between geographical memory, cultural trauma, and island spatiality. The main sources of data include two official publications of local records: one about the city's history in general, and the other with an exclusive focus on its hydrological history. Local newspaper reports are also referred to, all of which were published by the local Hengyang Daily after 2011, a period roughly coinciding with the initiation of a tourism master plan. Other data in written form include two sets of tourism promotional texts showcased on the island and two literary representations. Visual data are also gathered and considered, including online footage from the master plan, satellite images of the island before and after tourism development, and more than a dozen photos taken during either pre-planned fieldwork or leisure tours which took place in April 2018, January 2019, and July 2020. Two semistructured interviews with two island emigrants in April 2018 and several informal communications with a number of construction and service workers in both 2018 and 2019 have also informed the writing. Hard memory is abstracted based primarily on on-site and map observations and media analysis. Soft memory is approached through both textual and media analysis, while lived memory has been reconstructed through the processing of interviews and informal interaction. Traumatic experience is investigated by examining historical and literary texts, online discourse, and interviews.

\section{Dongzhou and geographical memory}

Places are often associated with diverse memories. Comparing political mourning in Russia and Germany, Etkind (2004) makes a distinction between soft memory and hard memory. Soft memory consists of literary and historical texts and other narratives, whereas hard memory is made up primarily of monuments and, in some cases, also state laws and court decisions. If hard memory is the responsibility of the state, soft memory is usually the process of society. Etkind (2004) also finds that soft memory appears to be dominant in post-Soviet Russia while hard memory is more often seen in post-Nazi Germany, though there are more nuanced specifics in both contexts.

The distinction between hard memory and soft memory is applicable to the case of Dongzhou Island as there is plenty of evidence for both. Etkind's approach, however, focuses 
solely on cultural and national memory of internal violence; the realm of civic experience is completely left out. When it comes to geographical memory, a third experiential category should be considered: lived memory. What follows is a brief overview of the three kinds of memory emanating from Dongzhou Island.

The local government initiated the dominant memory project on Dongzhou as part of the island's tourism development. The initiative constructs the island as a land of quintessential Chinese antiquity. As can be seen in its current morphology, the various tourism sites set in relief elements of Chinese antiquity from the island's northern tip to its southern extremity: a statue of a three-faced Goddess of Mercy, a restored Buddhist temple, an almost-reconstructed Confucian academy in the memory of a $17^{\text {th }}$-Century local bureaucrat-intellectual, an ancient tree, and a magnificent newly erected tower named after the aforementioned bureaucratintellectual. Island-mainland transport was also engineered to fit into the overall vision: there is now a newly built traditional Chinese-style covered bridge on the east bank of the island and a ferry terminal branded as 'Ancient Ferry' on the west bank. The linear distribution of these memory items is enabled by the particular spatiality of the island.

Dongzhou's rather narrow and oblong shape is typical of many river islands in the Xiangjiang River, which makes them relatively distinct from oceanic islands. The spatial parade of antique elements reinforces the impression of a fantastical neverland compared with its more differentiated surroundings on the riverbanks. A children's playground in the centralsouth part of the island is probably the only spectacular modern-style site. Its adjacency to the antique surroundings may look like a postmodern mélange to outsiders, but is in keeping with the overall vision of the island: a place of escapism, either in imagined history or projected future (Legend Tourism Investment \& Steinberg Architects, 2014).

Some of these hard memories come with textual inscriptions, conspicuously so at the sites of the academy and the tower. These inscriptions are either lyrical or expositional; contextualized narratives are largely absent. The combination of spectacular built landscape and non-narrative texts tends to induce more aesthetic responses than authentic historical understanding. During my third field trip in July 2020, the tower was temporarily closed to reduce management costs, as tourists were few. More nuanced historical semantics are also glossed over in the hard memories of the island. For example, Wang Fuzhi, the local bureaucrat-intellectual heavily branded in the project, is not a typical token of wise and benign Confucianism. He was reinterpreted by some as a representative of "provincial nationalism" (Platt, 2007, pp. 1-40), which could be difficult to embed in a contemporary cultural ideology equating nationalism with statism. In this regard, when it comes to unravelling historical details, books prove more useful than abstract, ritual-like monuments. 

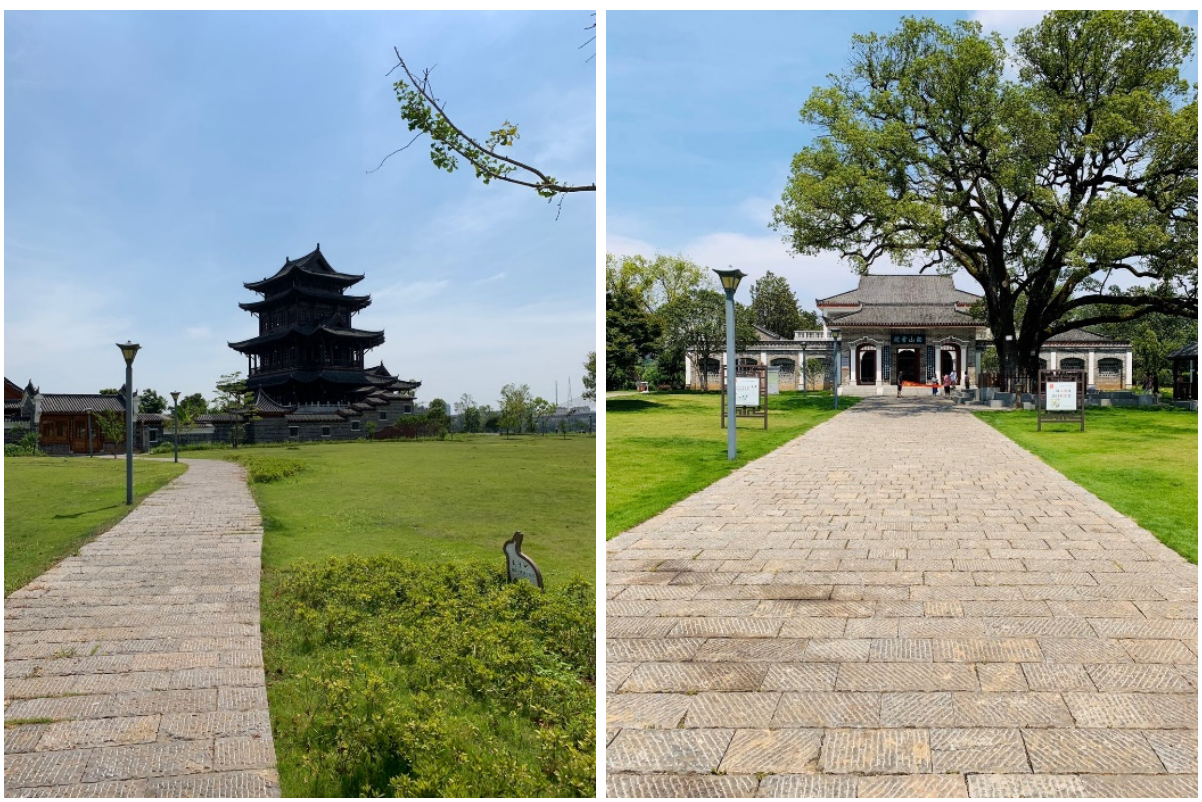

Figure 4: Left: The newly built Fuzhi Tower, commemorating Wang Fuzhi, an early-Qing Confucian intellectual recluse. Right: The reconstructed Chuanshan Academy also, named after Wang Fuzhi. Source: (C) Hong Gang, 2020.

Abundant soft memories also exist in diverse public forms, including historical texts, literary work, and video footage and articulations on social media. In comparison with hard memories, these soft ones have employed more historical narratives, but the dominant tendency is still lyrical and fragmentary, meaning that they are primarily employed to express one's feelings and emotion with limited contextual information. Representing the experiences and wishes of the civil world, these memories are significantly insulated from the island of hard memory. In terms of contents, they also tend to include more traumatic and nostalgic elements. For example, an oral history recounted by a veteran survivor of a mass torture killing of Chinese prisoners of war by the Japanese army in 1944 is anthologized in a thick book of official war memories in the context of Hengyang Defense Battle during the Second Sino-Japanese War (Huang, 2005, pp. 755-759). The Japanese selected Dongzhou Island as the location for a concentration camp due to its insulation and relative distance from the main town, but the event itself involved primarily captives from elsewhere (rather than islanders). Therefore, the historical account foregrounds the details of violence and suffering rather than the geographical location. As to literary texts, both poetry and prose exist depicting the island as a ruin on the rural-urban fringe due to social neglect in the earlier wave of urbanization which started in the 1990s. An intense feeling of being abandoned is palpable.

Another theme that emerges is characterized by a type of traumatic nostalgia in face of the cruel and inevitable change that the island has undergone during the recent tourism development. This memory, due to its freshness, is embodied mainly in new media forms such as video footage and civic articulations posted online. Local intellectuals' role in weaving island memories is minimal, though there is some scientific literature mentioning, in passing, the environmental degradation of the island (Hao et al., 2012; Huang et al., 2014; Li et al., 2015; Liu et al., 2011).

Lived memories of islanders are impossible to retrieve other than through vernacular channels, since the island-as a community-is gone. Even if these memories did get 
reconstructed, they would still be heavily influenced by mental processes of filtering and distortion, and could therefore by no means be treated as objective. My limited interaction with the islanders shows that their memories of the island are rich and pluralistic. Some prominent items and activities include flooded rural houses with only rooftops visible, selfdug drinking water wells, swimming as both daily commute and summer pastime, now-illegal blast fishing, and horrific and fascinating folklore about 'water monkeys'. Most of these memories have lost their physical anchorage now that the island has been turned into a purposefully engineered spectacle for the tourist gaze. Another important point is that, in the islanders' lived memories, Dongzhou was both impoverished and self-sufficient, both a shelter from the landed city and a backwater to escape from. Generational and class differences are crucial variables in this regard. This paradoxical perception of place is not unique to islandsit is perhaps at the very center of our complex relationship with the environment-but this trait makes these memories harder to sell as tourism and ideological commodities. Collectively, the willful and/or unconscious staging of certain memories at the expense of others will result in cultural amnesia. Since amnesia is a salient symptom of trauma, this issue compels us to further examine a particular kind of place memory: traumatic island memories.

\section{Dongzhou and cultural trauma}

From the perspective of cultural sociology, there are moral and political dimensions to trauma. Social groups may succeed or fail in participating in the process of trauma-making and hence solidarity-building. In this vein, cultural trauma is a problematic that is developed against what Alexander (2012, pp. 7-8) calls "lay trauma theory" that can be found in both lay and intellectual discourses. The theory is predicated on a myth of naturalism, that is, a perception of traumas as "naturally occurring events" (Alexander, 2012, p. 7) that shatter an individual or collective actor's sense of well-being. Accordingly, the experience of "being traumatized" (Alexander, 2012, p. 7) is thought of as an immediate and spontaneous reaction to such radical events. In response, Alexander (2012,p. 13) calls for a cultural understanding of trauma as a "socially mediated attribution," that is, a process of cultural-social construction boosted by what Durkheim (2008, p. 32) would call the "religious imagination." In this context, the word imagination is not synonymous with fiction or lies, as it would ordinarily sound. On the contrary, imagination is a force at the core of all cultural representations that "seizes upon an inchoate experience from life, and forms it [...] into some specific shape" (Alexander, 2012, p. 6, p. 14).

Alexander's highly reflexive model also presents detailed procedures for analysis. Pertinent steps of a sociological analysis of cultural trauma (Alexander, 2012) include:

1) claim making (symbolic representation of a feeling of fundamental injury with or without a related demand for reparation);

2) carrier group (individuals or groups making the above claim);

3) audience and situation (as in a speech act, a speaker and an audience are engaged in a situation);

4) institutional arena (trauma process is linked to power as exercised in religious, aesthetic, legal, scientific, media, and state bureaucracy arenas);

5) stratificational hierarchies (the distribution of material resources is uneven and the social networks provide different access to them). 
Three prominent traumatic histories of Dongzhou Island are profiled below: mass killing, radical planning, and uneven development. Whereas the first two involve violent force or radical change typically associated with traumatic experience, the third is more implicit in origin and more insidious in effect, but arguably no less traumatic in terms of subjective experience.

\section{Mass killing}

On August 8, 1944, the 48-day Hengyang Defense Battle came to an end as the Japanese army broke into the city of Henyang, in which the Chinese army was trapped with no prospect of rescue by allies, running out of both arsenals and food. Chinese military officials and soldiers were taken captive in several concentration camps within the city (Lv \& Jiang, 2015). Fang Xianjue, the commanding general of the $10^{\text {th }}$ Corps of the Chinese Nationalist army, was kept under house arrest in Renai Middle School; more than 200 military staff belonging to Division 190 were imprisoned in a concentration camp at the mouth of the Lei River; Division Officials above the rank of Chief of Staff were imprisoned in Huangcha Ling concentration camp, which was based in the Italian Catholic cathedral in today's Huangcha Ling; and hundreds of colonels, aids, and orderlies were locked up in the Dongzhou concentration camp, that is, Dongzhou Island. Besides these fixed camps, there were also several fluid camps outside the main town consisting of 300 to 500 prisoners working on infrastructure for the Japanese while travelling with them. These fluid camps promised a better chance of escape and survival because of their better access to food and hiding places on land.

In contrast, Dongzhou Island, surrounded by water on all sides, became a living hell isolated in the middle of the river. Its insularity was made worse by the fact that there was only one small boat for the Japanese to shuttle between the island and the mainland to purchase necessary supplies. The island's insularity resulted in a significant shortage of food for both the captors and the captives. Large quantities of pumpkins, a vegetable rich in sugar and other nutrients, were found near the beaches around the island-but the Japanese would not allow the Chinese soldiers to eat the pumpkins. Survivors bore witness to frequent instances of Chinese soldiers, driven by hunger, risking their lives by stealing into the pumpkin fields. Many were caught and subjected to gruesome torture-killing. One witness account describes stuffing Chinese soldiers' mouths with sharp split chopsticks in order to stop them from cursing while being fastened onto wooden poles and stabbed by the Japanese for bayonet drilling exercises. There were two documented large-scale carnages perpetrated by the Japanese at the island concentration camp (Huang, 2005).

Bullets supposedly left by the Japanese army were excavated during archeological trips to the island which were initiated as part of the tourism projects. The official Hengyang Daily mentioned the findings briefly, noting rather vaguely that these findings could enrich the "cultural connotations" of the island (Luo, 2017). In other contexts, the trauma of the siege and occupation have been re-enacted, although most accounts are popular contributions on social media (e.g., Yan City on a Palm, 2017). Leaving aside the veracity of these individual memories, they are certainly symptomatic of a civic need to account for these forgotten moments. The reason that the slaughter is not incorporated into the branding created to promote tourism on the island is understandable: cruelty of this scale and in such detail, although politically uncontroversial considering the overriding legitimacy of anti-Japanese sentiments 
in China, is perhaps too morbid to be assimilated into the overall marketing vision of the "island lure" (Baldacchino, 2012) associated with ancient wisdom and innocuous religiosity.

\section{Radical planning}

The most radical change experienced on the island was brought about by a wholesale tourism project initiated in 2010. This landmark event in the island's populated history has fundamentally altered the identity of the island as it has been transformed from an inhabited island village to an uninhabited tourist park. Globally, islands' susceptibility to radical place making fueled by radical geographical imagination can also be seen on other islands. For instance, dozens of islands and outport communities in Newfoundland and Labrador, Canada, were abandoned following a government resettlement policy which saw over 28,000 people removed from 307 outport communities (Brinklow, 2013; 2016). Another case is the 'Morichjhapi incident' in the archipelago in the Ganges delta, which involved the forced eviction of refugees from the island of Morichjhapi, in the northern-most forested region of the Sundarbans, in order to make way for Project Tiger (Fletcher, 2011).

Sporadic expressions of traumatic feelings related to this resettlement project can be found mainly online and through colloquial interaction with former islanders. This is probably due to the popular nature of social media. Salient subjects of the trauma discourse involve insufficient financial compensation (compensatory resettlement housing was provided by the city government based on the actual size of the family's original house on the island), loss of community, and dim prospects of being employed in the more urbanized landed city. In interviews with island emigrants, some likened the idea of permanently living off-island to "waiting to die." The sense of 'social death' experienced by some islanders is probably the most disturbing aspect of radical urban renewal. However, generational and class differences will certainly influence individual feelings towards and evaluation of the development model.

\section{Uneven development}

For the islanders, the status of Dongzhou Island was significantly inferior to that of the landed city. In interviews, one island emigrant's childhood memories of the island described it as a deprived backwater. The only way out was through education and employment through state-organized recruitment for factories in Hengyang. With the wave of urban expansion that began in the 2000s, the city has transformed much of its former suburbs where traces of their rural past still remain.

For example, take the aforementioned Confucian academy. It suffered a long period of neglect following 1949 as the nation's overall vision of urban development did not really integrate rural areas into the plan. A travelogue entitled The Mysterious and Wild Dongzhou Island, Hengyang depicts the academy as a site that is "abandoned and desolate" (Zou, 2011). In another instance, a fictional poem titled Embark on Dongzhou Island (Loner in Changsha, 2013) is set on a rainy day in April during the Festival of Pure Brightness, the traditional Chinese occasion to commemorate the dead. The poet positions readers as fellow flâneurs who are exploring the island with him in a misty and depressing milieu. Things that he sees include cracked traditional Chinese stone pavement, a decrepit academy built in the lateQing period, "broken bird chirping," old people abandoned by young men on the island, a "withered" ancient monument, and the "rusty sound of an ancient bell" (Loner in Changsha, 2013). The mood is symptomatic of the residents' emotional trauma associated with the 
languorous effects of uneven development. In comparison with the aforementioned traumatic memories, this description is more implicit, which probably explains why this memory finds an outlet mainly in literary form.

Traumatic affect has also been extended to the degradation of the island's natural environment due to long-term neglect and unregulated exploitation, as a local resident bemoans:

The bottom of Dongzhou Island is made up of pebble stones. Once washed away, how many more acres will be left for touristic development? What is lost cannot be restored. It is such heartache to watch such a precious resource subjected to such neglect. (Make plans before developing, 2014)

Some netizens also employ multimodal tools, such as vlogs and other video footages posted online, to give their traumatic affect more impact (Ldlandy, 2018).

\section{Summary}

For clarity's sake, different aspects of trauma constructions are listed as follows:

Table 1: Aspects of trauma constructions identified on Dongzhou Island.

\begin{tabular}{|c|c|c|c|}
\hline \multirow[t]{2}{*}{ Aspect } & \multicolumn{3}{|l|}{ Trauma construction } \\
\hline & Mass killing & Radical planning & Uneven development \\
\hline $\begin{array}{l}\text { Claim } \\
\text { making }\end{array}$ & $\begin{array}{l}\text { Violence against the } \\
\text { Chinese people }\end{array}$ & $\begin{array}{l}\text { Loss of home, island life, } \\
\text { and underrepresented } \\
\text { economic rights }\end{array}$ & $\begin{array}{l}\text { Environmental } \\
\text { degradation; Social } \\
\text { underdevelopment }\end{array}$ \\
\hline $\begin{array}{l}\text { Carrier } \\
\text { groups }\end{array}$ & $\begin{array}{l}\text { Non-islander veteran } \\
\text { survivors; Some islanders }\end{array}$ & Some islanders & $\begin{array}{l}\text { Local poets; Local } \\
\text { tourists; Some islanders }\end{array}$ \\
\hline $\begin{array}{l}\text { Audience \& } \\
\text { situation }\end{array}$ & $\begin{array}{l}\text { General public, } \\
\text { especially through } \\
\text { intellectual channels }\end{array}$ & $\begin{array}{l}\text { Netizens on online } \\
\text { forums; Non-islander } \\
\text { residents in vernacular } \\
\text { interaction }\end{array}$ & $\begin{array}{l}\text { The literary public; } \\
\text { Netizens; Non-islander } \\
\text { residents in vernacular } \\
\text { interaction }\end{array}$ \\
\hline $\begin{array}{l}\text { Institutional } \\
\text { arenas }\end{array}$ & $\begin{array}{l}\text { Social scientific arena; } \\
\text { State bureaucracy arena; } \\
\text { Mass media, new media }\end{array}$ & $\begin{array}{l}\text { Social media; Everyday } \\
\text { life }\end{array}$ & $\begin{array}{l}\text { Literary journal; Social } \\
\text { media; Everyday life }\end{array}$ \\
\hline $\begin{array}{l}\text { Stratificational } \\
\text { hierarchies }\end{array}$ & $\begin{array}{l}\text { Limited visibility in } \\
\text { public sphere due to } \\
\text { small scale of event and } \\
\text { restricted understanding } \\
\text { of cultural heritage in } \\
\text { tourism agenda }\end{array}$ & $\begin{array}{l}\text { Limited visibility in } \\
\text { public sphere due to } \\
\text { conflicts of economic } \\
\text { interest and more } \\
\text { fundamental dilemma of } \\
\text { urban development in } \\
\text { China }\end{array}$ & $\begin{array}{l}\text { Limited visibility in } \\
\text { public sphere due to } \\
\text { failure to recognize lost } \\
\text { everyday island life as } \\
\text { heritage and dominance } \\
\text { of development } \\
\text { discourse built on myth } \\
\text { of progress }\end{array}$ \\
\hline
\end{tabular}

In summary, the three events have disrupted island life and altered island identity on Dongzhou Island, and they have been subject to different forms of trauma construction. The current study has found that there is much soft memory, and none of these traumatic histories have been staged as hard memory. While the hard memory projects construct the island as a 
petrified landmark, the soft memories murmur about the forgotten or obscured pains of a small island that bears witness to the violence of war and progress.

\section{Conclusion}

A vast array of memories has emanated from the small island of Dongzhou. The conspicuous presence of hard memory is embodied in its current spectacular built landscape. By crafting the island into a landmark, the present tourism project attempts to envision a future by creating a link to the city's imagined past. Meanwhile, a plethora of soft memory articulations are manifested mainly through textual and symbolic means. They speak quietly about difficult and dark aspects of the island's history. These two types of memory coexist in virtual isolation from each other, and are complemented in our analysis by the least-visible variety of memory: the lived memories of former islanders. Their memorizations of the island are not necessarily more objective, but are often physically anchored to the island and its riverine surroundings as inhabited space. They are paradoxical, yet semantically rich and pluralistic.

A deeper way to examine the memories of the island is to consider how traumatic histories are represented and articulated. Three major traumatic histories are identified: mass killing near the end of the Second World War, forced relocation for tourism development in the 2010s, and social neglect in a previous wave of uneven development before the mid2000s. These constructions of cultural trauma make different claims and have different carrier groups but, addressed to a vague local public, they exist exclusively in the form of soft memory and have limited social visibility due to both economic and cultural constraints. This brings us to the role of place memory in rejuvenating local cultures.

In 2017, the State Council of China issued a series of directives aiming at a rejuvenation of 'quintessential' traditional Chinese culture (Xinhua News Agency, 2017). A prominent component of these directives deals with the heritagization of local city culture against the backdrop of the homogeneous development trend across China over the past 15 years or so. In a way, there is no turning back from the "juggernaut" of modernity (Giddens, 1991, p. 151) and the possibility of a genuine bottom-up development model is limited considering contemporary China's politico-economic structure.

A way to seek alternative trajectories for rejuvenating small islands and local space such as Dongzhou perhaps lies in a complementary cultural model integrating different aspects of island histories and island geographies and representing them in diverse ways. In terms of content, the contemporary, everyday, and traumatic memories should all be recognized as vital heritage of a place that is no less important (or, in some cases, even more important) than crafted memories of a visionary past. Globally, there has been increasing awareness of the crucial legacies of violence and trauma for the historical continuity of a culture (Adamek, 2016; Bauer-Clapp, 2016; Dwiggins, 2016; Paynter et al., 2016; Sheppard-Simms, 2016; Weber, 2016). In terms of form, the affective and the experiential should be included alongside the physical and the representational. Participatory narrativity, as opposed to static monumentality, should also be given a more central place. In general, a rethinking of what constitutes heritage and how to construct local space in a way that incorporates diverse memories is good for the island, city, and nation as a whole.

Last but not least, this research has several theoretical and practical implications. The primary one concerns island studies' research focus. If studying island memories is worthwhile 
at all, it can only be attributed to the fact that small islands such as Dongzhou are changing so rapidly (arguably more so than some other geographies) that we need to pause and reflect on what should be preserved, reconstructed, and carried into the future. As Hayward (2018) says, "to be an islander is, increasingly, to live in flux. To be an Island Studies scholar is, increasingly, to be scholar of flux." While it is a platitude that no cultural symbolism or theorization can do justice to past experiences, it is intellectually and ethically necessary for island studies scholars to become a medium between islands' past and present, and different versions of islands' past memorialized by different groups. A project of this kind inevitably involves more cross-disciplinary consciousness and methodological innovation. A formulaic mixing of methodologies across disciplines may not be a herculean task, but an earnest integration in the service of research objectives demands no small effort; disciplines share a will to knowledge, but also often an obsession with their imagined boundaries.

Back in the real world, memory is related to history, but it is not history; it is relational and implicated with meaning production and identity construction. In remembering a past, we are actually projecting a future. Therefore, studying island memories is neither reactionary nostalgia nor intellectual pastime. The physical islandscapes may be mutable, but we can decide which island memories we will carry with us into the future.

\section{Funding}

This research article was supported by the General Program of the National Social Science Fund of China (Grant No. 19BWW090). 此研究论文受到中华社会科学基金资助（批 准号：19BWW090），为 2019 年度国家社会科学基金项目（一般项目）阶段性成果

\section{References}

Adamek, D. (2016). Zasto: Belgrade and the remains of the NATO bombing. Landscapes of Violence, 4(1), 6.

Alexander, J.C. (2012). Trauma: A social theory. Polity.

Atkinson, M., \& Richardson, M. (Eds.). (2013). Traumatic affect. Cambridge Scholars Publishing.

Baldacchino, G. (2008). Studying islands: On whose terms? Some epistemological and methodological challenges to the pursuit of island studies. Island Studies Journal, 3(1), 37-56.

Baldacchino, G. (2012). The lure of the island: A spatial analysis of power relations. Journal of Marine and Island Cultures, 1(2), 55-62. https://doi.org/10.1016/j.imic.2012.11.003

Baldacchino, G. (Ed.). (2015). Entrepreneurship in small island states and territories. Routledge. https://doi.org/10.4324/9781315764528

Ball, P. (2017). The water kingdom: A secret history of China. University of Chicago Press. https://doi.org/10.7208/chicago/9780226470924.001.0001

Bauer-Clapp, H. (2016). Heritage of violence: Editor's introduction. Landscapes of Violence, 4(1), 1.

Brinklow, L. (2013). Stepping stones to the edge: Artistic expressions of islanders in an ocean of islands. Island Studies Journal, 8(1), 39-54. 
Brinklow, L. (2016). A man and his island: The island mirror in Michael Crummey's 'Sweetland'. Island Studies Journal, 11(1),133-144.

Caruth, C. (1996). Unclaimed experience: Trauma, narrative, and history. Johns Hopkins University Press.

Caruth, C. (1995). Trauma: Explorations in memory. Johns Hopkins University Press.

Durkheim, E. (2008). C. Cosman (Trans.). The elementary forms of religious life. Oxford University Press.

Dwiggins, J. (2016). The troubled past and contested future of Northern Ireland's Maze Prison/Long Kesh. Landscapes of Violence, 4(1), 3.

Etkind, A. (2004). Hard and soft in cultural memory: Political mourning in Russia and Germany. Grey Room, Summer(16), 36-59. https://doi.org/10.1162/1526381041887439

Felman, S. (2002). The juridical unconscious: Trials and traumas in the twentieth century. Harvard University Press.

Fletcher, L. (2011). Reading the postcolonial island in Amitav Ghosh's 'The Hungry Tide'. Island Studies Journal, 6(1), 3-16.

Foote, K. (2003). Shadowed ground: America's landscapes of violence and tragedy (2nd ed.). University of Texas Press.

Giddens, A. (1991). The consequences of modernity. Polity.

Gillis, J.R. (2007). Island sojourns. Geographical Review, 97(2), 274-287. https://doi.org/10.1111/j.1931-0846.2007.tb00403.x

Gregory, D., Johnston, R., Pratt, G., Watts, M.J., \& Whatmore, S. (Eds.). (2009). The dictionary of human geography (5th ed.). Wiley-Blackwell.

Halbwachs, M. (1992). On collective memory. The University of Chicago Press.

Hao, Y., Zhang, M., Tan, S., Zhou, Y., Xue, J., Xiang, Y., \& Quan, S. (2012). The seasonal fluctuation and diversity of aquatic nematode-trapping fungi. Journal of University of South China (Science and Technology), 26(1), 87-92.

Hayward, P. (2018, March 30-April 1). Keynote: Formulations in flux [Conference presentation]. Archipelagos and Aquapelagos: Conceptualising Islands and Marine Spaces Conference, Pratt Institute, Brooklyn, NY, United States.

Hengyang Municipal Chronicle Office. (Ed.). (2014) Hengyangshizhi 1978-2008 [Hengyang municipal chronicle 1978-2008]. Beijing: Publishing House of Local Records.

Herman, J. (1992). Trauma and recovery: The aftermath of violence - From domestic abuse to political terror. Basic Books.

Huang, C., \& Peng, H. (2012). Research on the development of islets in rivers of Xiang River basin. Journal of Hengyang Normal University, 33(6), 93-96.

Huang, C., Peng, H., \& Mei, J. (2014). Research on evaluation of recreation ecological security for islet in river of city: a case study of Dongzhou Islet in Hengyang city, Hunan province. Science and Technology Management Research, 19, 241-250.

Huang, Z. (2005). Hengyangbaoweizhanhou rijunjizhongyingcanhaizhanfuxueleiji [Tears and blood records of Japanese persecution in war prisoners' concentration camps after the Hengyang Defense Battle]. In Hengyang Committee of the Chinese People's Political Consultative Conference. (Ed.). Hengyang kanzhan zhumingcheng [Hengyang as a famous city forged by the resistance war] (Chinese). China Press of Literature and History. 
Kelman, I. (2020). Islands of vulnerability and resilience: Manufactured stereotypes? Area, 52(1), 6-13. https://doi.org/10.1111/area.12457

Kuang, M., \& Rao, Q. (2008). Hengzhou xianzhi [Official records of Hengzhou during Emperor Qianlong's period (Vol. 1)] (Chinese). Yuelu College Press.

Laud, D., \& Auerhahn, N.C. (1993). Knowing and not knowing massive psychic trauma: Forms of traumatic memory. International Journal of Psychoanalysis, 74(2), 287-302.

Ldlandy (2018). Dongzhou Islands before and after development. Youku. http://v.youku.com/v show/id XMzM4NTMyODM4NA==.html?spm=a2h0k.81 91407.0.0\&from $=\mathrm{s} 1.8-1-1.2$

Legend Tourism Investment \& Steinberg Architects (2014). Municipal tourism conceptual plan. Accessed on $15^{\text {th }} \quad$ March 2018. http://v.youku.com/v show/id XNzUyNjY5NTc2.html.

Li, Y., Wang, L., Chen, X., Teng, T., Zhou, D., Liu, Z., \& Wang, T. (2015). Investigation and research of root-knot nematode disease in towel gourd field in Dongzhou Island. Journal of Hengyang Normal University, 36(3), 123-126.

Liu, J., Wu, Y., Li, J., Hu, J., Li, P., \& Liu, Y. (2011). Investigation of the diversity of mollusca and evaluation of water quality in Hengyang reach of Xiangiiang River. Environmental Monitoring in China, 27(2), 97-101. https://doi.org/10.1109/RSETE.2012.6260802

Loner in Changsha (2013). Deng Dongzhoudao [Embark on Dongzhou Island] (Chinese). Xingxing, 1st Section of 2013, 128.

Luo, W. (2017). The first finding of bullets left by the Japanese army on Dongzhou Island. August 24, Hengyang Evening Paper. http://epaper.hyqss.cn/hywb/html/2017$\underline{08 / 24 / \text { node } 3 . h t m}$

Lv, X., \& Jiang, S. (2015). Hengyang baoweizhan: Mengduan Hengyangcheng, yingxiangquanjilu [Hengyang defense battle: Broken dreams in the city of Hengyang, a graphic document] (Chinese). Changcheng Press.

Make plans before developing (2014). Make plans before developing Dongzhou Island. Rednet. http://people.rednet.cn/PeopleShow.asp?ID=1907405

Massey, D. (2005). For space. Sage. https://doi.org/10.12968/sece.2005.1.361

Nora, P. (1997). Realms of memory. Columbia University Press.

Paynter, B., Hoque, M., Marifat, H., \& Monicelli, E. (2016). Witnesses and the changing goals of memorialization. Landscapes of Violence, 4(1), 5.

Platt, S.R. (2007). Provincial patriots: The Hunanese and modern China. Harvard University Press.

Pugh, J. (2018). Relationality and island studies in the Anthropocene. Island Studies Journal, 13(2), 93-110. https://doi.org/10.24043/isj.48

Sheppard-Simms, E.A. (2016). Islands of the abject: Absence, trauma and memory in the cemetery island. Landscapes of Violence, 4(1), 2.

Till, K. (2005): The new Berlin: Memory, politics and place. University of Minnesota Press.

Trauma (n.d.). In Merriam-Webster's collegiate dictionary. https://www.merriamwebster.com/dictionary/trauma

Tuan, Y.F. (1977). Space and place: The perspective of experience. University of Minnesota Press.

Tuan, Y.F. (1990). Topophilia: A study of environmental perception, attitudes, and values. Columbia University Press. 
van der Kolk, B.A. (2014). The body keeps the score: Mind, brain and body in the transformation of trauma. Viking.

Water Resources Chronicle Office of Hengyang Municipal Water Resources Bureau (Ed.). (2014). Hengyang shuilizhi [Hengyang municipal water resources chronicle] (Chinese). Publishing House of Local Records.

Weber, S. (2016). Notes from the field: Rebuilding lives among memories of violence. Landscapes of Violence, 4(1), 4.

Xinhua News Agency (2017, January 25). The General Office of the Central Committee of the Communist Party of China and the General Office of the State Council issued the 'Opinions on the Implementation of the Inheritance and Development Project of Chinese Excellent Traditional Culture' (Chinese). Xinhuanet. http://www.xinhuanet.com//politics/2017-01/25/c 1120383155.htm

Yan City on a Palm. (2017, September 2). Hengyang, a fading heroic city. Weixin. https://mp.weixin.qq.com/s/sijUJ0flI5yrgLixw9vktw

Zou, L. (2011, September 26). Shenmiyexing Hengyangdongzhoudao [The mysterious and wild Dongzhou Island, Hengyang] (Chinese). Blogsina. http://blog.sina.com.cn/s/blog 73c601080100wzbj.html 